\title{
GUBICI OSOVINSKE AVIJACIJE U APRILSKOM RATU 1941
}

\begin{abstract}
APSTRAKT: U članku su prikazani gubici sila Osovine u ljudstvu i letelicama tokom operacija protiv Kraljevine Jugoslavije u aprilu 1941. godine, kao i okolnosti pod kojima se to dogodilo. Upoređeni su i sravnjeni različiti podaci. Ovaj rad posvećen je svim onim vazduhoplovcima Kraljevine Jugoslavije koji su, uprkos svemu, uzletali, borili se i ginuli, iako su dobro znali svoje mogućnosti, naročito protiv tada najmoćnijeg vojnog vazduhoplovstva na svetu. Takođe je sećanje i na protivavionce. Neka nas ovi redovi bar malo podsete na njih, na 70-godišnjicu ovih događaja.
\end{abstract}

Ključne reči: Aprilski rat, Balkan, avijacija, gubici, Drugi svetski rat, Kraljevina Jugoslavija

Aprilski rat 1941. godine trajao je svega 12 dana, ali manje od jedne nedelje bilo je povoljno za letenje. To su samo neke činjenice uzete u obzir za procenu gubitaka nanetih neprijatelju. Da li je nekih 164 aviona izgubljenih ili izbačenih iz stroja na suprotnoj strani malo ili mnogo? U ratu protiv Poljske, septembra 1939, Treći rajh je upotrebio više vazduhoplova nego protiv Jugoslavije, a borbe su trajale mesec dana. Tada su nemačke vazduhoplovne snage (Luftwaffe Luftvafe) izgubile oko 260 letelica, a još oko 100 je teže oštećeno. ${ }^{1} \mathrm{Za}$ dejstva protiv Danske i Norveške, 1940. godine, uzet je nešto manji broj aviona nego prema Kraljevini Jugoslaviji. ${ }^{2}$

$\mathrm{Na}$ zapadu Evrope sukob je bio rovovski, sličan Prvom svetskom ratu, sve do početka velike nemačke ofanzive, 10. maja 1940. Nemci su već prvog dana te ofanzive izgubili 304 aparata i imali 51 teško oštećen avion, što je više od svih borbenih gubitaka nemačkog vazduhoplovstva od početka Drugog svetskog rata. ${ }^{3}$ Korišćene snage bile su nekoliko puta veće, ali na manjem prostoru nego na Balkanu 1941. godine.

\footnotetext{
${ }^{1}$ Jerzy B. Cynk, Polskie zwyciestwa mysliwskie we wrzesniu 1939 (III), Uwagi, refleksje, wnioski, AERO technika lotnicza, Warszawa, numer 4, 1990, 38 и 39.

${ }^{2}$ Vojislav V. Mikić, Nemačka avijacija u Jugoslaviji 1941-1945 (dalje: Nemačka avijacija..), Beograd 1998, 8.

${ }^{3}$ Air warfare and military aviation, Guinness, London 1990, 188.
} 
Tokom vazdušne Bitke za Britaniju, od jula do oktobra 1940, prema nemačkim podacima Britancima je oboreno 915 aviona a Nemci su izgubili 1.733 vazduhoplova. Nemačka je u istom periodu izvršila 783 vazduhoplovna napada na Englesku, a Britanci 601 napad iz vazduha na Nemačku. ${ }^{4}$

Italijansko kraljevsko vazduhoplovstvo (Regia Aeronautica - Ređija Aeronautika) bilo je manje od nemačkog, pa tako i njihove snage predviđene za napad na Jugoslaviju. ${ }^{5}$ Svoje borbeno iskustvo steklo je pre Drugog svetskog rata na nebu Španije zajedno sa nemačkom legijom „Kondor“, a posle iznad Francuske, severne Afrike, Malte, Velike Britanije i Grčke. Zahvaljujući brojnosti lako je postiglo prevlast u vazduhu, ali su retki avioni jugoslovenskog vazduhoplovstva uspešno leteli protiv njih. Polovično popunjene jedinice, osrednje borbene vrednosti i niskog morala, uglavnom nisu predstavljale problem jugoslovenskoj vojsci. Italijansko vazduhoplovstvo je od 6. do 16. aprila 1941, u operacijama protiv Kraljevine Jugoslavije, izvršilo ukupno 1.468 avio-poletanja. ${ }^{6}$

Mađarsko kraljevsko vojno vazduhoplovstvo (Magyar Honved Királyi Légierő - Mađar Honved Kiralji Legiero), malo je letelo u poređenju sa nemačkim i italijanskim vazduhoplovstvom. Mađari su imali većinom zastarele mašine, naročito lovačke. Njihovi piloti su bez uspeha krstarili nad svojom teritorijom, naletevši oko 600 časova, ne oborivši pri tom nijedan jugoslovenski aeroplan, ali je zato njihova protivavionska artiljerija srušila nekoliko jugoslovenskih aviona. Oni su tek četvrtog dana rata prvi put uleteli u jugoslovenski vazdušni prostor. Nekoliko dana kasnije mađarska vojska zauzela je veći deo Vojvodine i tako završila svoju prvu bitku u Drugom svetskom ratu. U tih nekoliko dana vreme je uglavnom bilo loše za letenje, otpor jugoslovenskih trupa slab, pa izuzev izviđačkih letova i jednog neuspešnog padobranskog desanta kao i bombardovanja sopstvenih trupa, drugih akcija nije bilo. ${ }^{7}$ Bugarska i Rumunija su ustupile svoju teritoriju nemačkoj vojsci za operacije protiv Jugoslavije. Iako su sa njihovih aerodroma poletali nemački avioni u napad na Jugoslaviju, domaće vazduhoplovne snage su izmeštene da čuvaju vazdušni prostor iznad sopstvenih istočnih granica.

\footnotetext{
${ }^{4}$ Greiner/Schramm, Srbi u ratnom dnevniku Vermahta, Beograd 2003, 39.

${ }^{5}$ Vojislav V. Mikić, Italijanska avijacija u Jugoslaviji 1941-1943 (dalje: Italijanska avijacija...), Beograd 1998, 10-12.

${ }^{6}$ Isto, 20; V. Mikić, Nemačka avijacija..., 42. - U ovom delu Mikić navodi nešto drugačije podatke o naletu italijanske avijacije - 1.841 avio-poletanje. Dodatni letovi su obavljeni verovatno samo nad sopstvenom teritorijom radi njene zaštite iz vazduha od eventualnog napada protivničke avijacije. Na ovakav zaključak navodi činjenica da je razlika u broju poletanja samo među lovačkim avionima, dok je kod drugih vrsta avijacije nalet isti. Svi podaci o naletu italijanske avijacije u Mikićevim delima preneti su iz knjige italijanskog vazduhoplovnog istoričara, generala Đuzepea Santora.

${ }^{7}$ Pataky Iván, Rozsos Lászlo, Sárhidai Gyula, Légi háború Magyarország felett, I, Zrínyi Kiadó, Debrecen, 1992, 43-58; Horváth Csaba, Lengyel Ferenc, A délvidéki hadmüvelet 1941. április, Puedlo Kiadó, Kaposvár, sine ano; Мирко Стојнић, Априлски рат виђен са друге стране, Зборник радова меморијалног скупа: Учешће Ваздухопловства Војске у Априлском рату 1941, 3. и 4. април 1995 (даље: Зборник...), Београд 1995, 137-142.
} 
Vlade tih monarhija su još u Aprilskom ratu protestovale kod jugoslovenske vlade povodom bombardovanja njihove „neutralne“ teritorije od strane jugoslovenskog vazduhoplovstva. ${ }^{8}$

Jedina susedna država u kojoj tada nije bilo neprijatelja bila je Grčka, gde su se nalazili ondašnji jugoslovenski saveznici: britanska i grčka vojska. Međutim, zbog istovremenog pohoda sila Osovine na obe zemlje izostalo je savezničko sadejstvo. Kraljevina Jugoslavija je zapravo bila opkoljena, a u tako nepovoljnom položaju bila je možda samo još Poljska. Zbog izjava hrvatskih i slovenačkih političara da se njihovi sunarodnici neće boriti van granica sopstvenih banovina, jugoslovenski generalštab morao je iz političkih razloga, suprotno vojnim načelima, da usvoji kordonski raspored odbrane na samim granicama. ${ }^{9}$ Tako su još više razvučene ionako nedovoljne snage. Napadač je, pored brojčane premoći, zato imao i lakši izbor vremena i mesta udara sa kopna i iz vazduha. Pošto je početak pripao njemu, to je mogućnost postizanja iznenađenja bila veća. Time su stvorene pretpostavke za uspeh neprijatelja a braniocu otežan otpor i nanošenje gubitaka protivniku.

Vazduhoplovstvo vojske Kraljevine Jugoslavije bilo je nedovoljno popunjeno novim vazduhoplovima i iskusnim letačima, iako je posedovalo više savremenih vojnih aviona od Francuske u vreme Minhenske krize, Poljske početkom Drugog svetskog rata ili Holandije u metropoli tokom napada na nju. ${ }^{10}$ Mali broj osposobljenih ratnih letelišta nije u potpunosti omogućavao da se iskoristi prebacivanje avijacije na njih radi izbegavanja neprijateljevih vazduhoplovnih udara po jugoslovenskim vazduhoplovnim jedinicama dok su prizemljene. Premda su Nemci neke jugoslovenske vazduhoplovne snage iznenadili budući da su ih zatekli na tlu, oni nisu uvek uspevali da u potpunosti iskoriste trenutak iznenađenja. Tada su pojedini jugoslovenski piloti uspevali da uzlete i počnu borbu ili da pobegnu na drugi aerodrom i tako prežive do sledećeg zadatka. U prvim danima rata nije bila primenjena najbolja taktika, što je odraz neiskustva, malodušnosti ali ponegde i rada pete kolone.

Kapetan I klase Vladimir Kren prebegao je iz Zagreba u Grac u Nemačkoj, 3. aprila 1941, ponevši podatke o ratnom rasporedu letačkih jedinica jugoslovenskog vazduhoplovstva, aerodroma, spiskova mobilizacijskih mesta, komandi, jedinica i ustanova, kao i šifru za radio-vezu vazduhoplovstva. ${ }^{11}$ Sve je predao Nemcima. Zato je Štab vazduhoplovstva vojske noću 5/6. aprila 1941. promenio šifru, ali

${ }^{8}$ Velimir Terzić, Slom Kraljevine Jugoslavije 1941, knjiga 2, drugo izdanje, Beograd 1984,323 и 482.

${ }^{9}$ Миодраг Ј. Ђорђевић, Павелићев пуковник Иван Бабић и његови разговори са Новом Хрватском, Windsor, 1980; Živko Avramovski, Britanci o Kraljevini Jugoslaviji, 1939-1941, knjiga 3, Beograd 1996, 814; Boris Ciglić \& Dragan Savić, Dornier Do 17, The Yugoslav story, Operational Record 1937-1947, jeroplan books, Belgrade 2007, 27.

${ }^{10}$ Prema istraživanjima dr Mileta Bjelajca u francuskim arhivima, Treća republika je u to vreme raspolagala sa manje od 200 letelica prve linije. Poljska je 1939. godine posedovala samo 106 savremenih bombardera PZL-37, ali je svega 50 moglo da se upotrebi u borbi. Holandija je 1940. imala ukupno 146 aviona.

${ }^{11}$ V. Terzić, $n$. d., 292. 
je obaveštenje potčinjenim trupama o tome kasnilo, delimično i sabotažom petokolonaša u jugoslovenskom vazduhoplovstvu. Taktika lovačkog boja jugoslovenskog vazduhoplovstva bila je zastarela za sukob protiv lovaca, dok je protiv bombardera i ostalih vrsta avijacije bila prihvatljiva. U ratu je pokušana i primena nemačkog obrasca koji je tada bio najbolji a koristi se i danas u vojnim vazduhoplovstvima. Uprkos svemu, učinak jugoslovenskih pilota bio je iznad očekivanja ali hrabrost nije mogla da zameni sadržajnije školovanje, veštinu koja se njime stiče, kao i borbeno iskustvo. ${ }^{12}$

Izvežbanost u letu, odnosno godišnji nalet jugoslovenskih pilota bio je nedovoljan za potrebe modernog ratovanja. ${ }^{13}$ Nemački pilot je po izlasku iz pilotske škole (dakle pre odlaska u ratnu jedinicu) imao oko 150 časova naleta ${ }^{14}$ a od toga trećinu na lovačkom avionu tipa Meseršmit 109, za manje od godinu dana. Osim toga on je u školskoj grupi svoje eskadre (gešvadera) provodio određeno vreme u višoj obuci, učeći se letenju u borbi, skupnoj taktici, usavršavajući gađanje meta. Tu bi naleteo još oko 100 sati i tek onda išao na ratne zadatke, predvođen iskusnim letačima. Od nemačkih pilota koji su obarali jugoslovenske avione u ratu aprila 1941. godine, svega nekoliko tada nisu bili asovi, u stvari bili su sa manje od pet priznatih pobeda u vazduhu odnosno uništenja protivničkih aviona. Većina je do balkanske kampanje, na drugim ratištima, postigla između 10 i 25 pobeda a neki i preko $30{ }^{15}$

Jugoslovenski letači su sakupili prosečno do 50 sati naleta na Meseršmitovom lovcu (kojih je u naoružanju bilo najviše), ${ }^{16}$ a od 300 do ukupno 900 sati

12 Šime Oštrić, Avijacija aprilskog rata, Front, Beograd, br. 1132, 11. april 1980, 23. - Posle nekih provera Oštrić je procenio 47 pobeda jugoslovenskih pilota i 24 verovatne. Poređenja radi, braneći svoju otadžbinu poljski piloti lovci prijavili su 126 pobeda u vazduhu nad nemačkim letelicama ali su Nemci tada imali manje iskustva. U borbama iznad nemačko-francuske granice, u vremenu od izbijanja sukoba do početka velike nemačke ofanzive u maju 1940, francuski piloti lovci na Moranu 406 (koji je bio najbrojniji avion te namene $\mathrm{u}$ francuskoj avijaciji) oglasili su obaranje 48 neprijateljevih vazduhoplova, od čega im je priznato 32. U borbama maja i juna iste godine, letačima istog tipa aviona pripisano je rušenje 280 protivnikovih aparata a potvrđeno 192. Grčki avijatičari su 1940-41. prijavili 58 italijanskih i pet nemačkih uništenih mašina uz još 23 verovatne. Belgijski, norveški i holandski vazduhoplovci prilikom napada na njihove države protivniku su ukupno naneli gubitaka koliko i jugoslovenski piloti. Austrijske, danske, češke i slovačke posade u istoj situaciji nisu ni uzletele. Jugosloveni su istraživanjima posle rata sveli svoj zbir na oko 50 potencijalnih žrtava a za oko 30 njih su nađeni podaci u arhivi druge strane.

${ }^{13}$ Драган Шалер и Предраг Миладиновић, Технички аспекти авијације у пионирском добу, Браничево кроз војну и културну историју Србије II, свеска 4, Историјски архив Пожаревац, 2007, 348; Марио Хреља и Бојан Димитријевић, Април 1941, Ловачки авиони Ваздухопловства Војске Краљевине Југославије/April 1941 Fighters of the Royal Yugoslav Air Force, Наша крила, специјално издање, Београд, април 2001, 6. Isto se dogodilo srpskim pilotima u I i II balkanskom ratu a takođe i u ratu protiv NATO 1999. godine.

${ }^{14}$ Len Deighton, Lovac, Zračna bitka za Britaniju, svezak prvi, Zagreb 1984, 166; Piter Taunsend, Dvoboj orlova, Beograd 1979, 121.

${ }^{15}$ Jochen Prien, Gerhard Stemmer, Peter Rodeike, Winfried Bock, Die Jagdfliegerverbände der Deutschen Luftwaffe 1934 bis 1945, Teil 5 ... Einsatz im Mittelmeeraum, Oktober 1940 bis November 1941...(dalje: Die Jagdflieger...), Struve druck, Eutin 2003.

${ }^{16}$ Zoran Jerin, Emil versus Luftwaffe, Air Enthusiast, London, Vol 1, No 4, September 1971, 210. - Kao presek dovoljno je navesti slučajan uzorak pregleda naleta nekih pilota boraca iz 
na svim vrstama vazduhoplova koje su koristili do tada. Slično je i sa naletom jugoslovenskih pilota na Harikenu ili IK-3. Mali broj raspoloživih savremenih aviona još više su umanjivali česti kvarovi ili udesi koji su bili neminovni u preobuci. Budući jugoslovenski piloti lovci upućivani su i pre završetka obuke u svoje jedinice da je tamo dovrše jer je Pilotska (Lovačka) škola mogla da ih primi u ograničenom broju. $^{17}$ To je takođe snižavalo nalet osposobljenim pilotima u eskadrili. Od dolaska Hitlera na vlast nemačke pilotske škole obrazovale su 800 pilota godišnje. ${ }^{18} \mathrm{Ju}-$ goslovensko vazduhoplovstvo je pred rat u aprilu 1941. raspolagalo sa oko 2.000 pilota. ${ }^{19}$ Većina jugoslovenskih letača trebalo je da za manje od godinu dana upozna i sasvim usvoji pilotiranje najnovijim lovačkim i ostalim mašinama, što je sa malim naletom bilo nemoguće. Ovako kratak vremenski rok posledica je kasnog uvođenja modernih aviona u naoružanje. Brže preoružanje, pored nedostatka novca za kupovinu u inostranstvu i povremenih zabrana izvoza vazduhoplova, otežavao je i munjevit razvoj vazduhoplovne tehnike pa su, pre svih, lovački avioni zastarevali za samo godinu dana. Mnoga veća vazduhoplovstva, čak i u pogledu brojnosti, nisu bila u boljem položaju ali su većim izvorima i snagom svojih država mogla to brzo da nadoknade. Francuska je u poslednjih godinu dana mira povećala broj novih aparata sa manje od 200 na više od $1.400 .^{20}$ Slično je bilo i u Velikoj Britaniji. Male države, među njima i Kraljevina Jugoslavija, jednostavno nisu mogle da prate takvo ubrzanje u naoružavanju ma kako bile privredno razvijene. ${ }^{21}$

Nemci su protiv Kraljevine Jugoslavije angažovali 1.412 aviona ili oko $28 \%$ sopstvenog borbenog ešalona. Međutim, ostatak njihovih snaga stajao je na raspolaganju kao neiscrpna rezerva za popunu gubitaka ili ojačavanje jedinica u slučaju potrebe, jer je samo manji deo preostalih efektiva učestvovao u dejstvima protiv Velike Britanije i na Sredozemlju. ${ }^{22}$ Italijani su upotrebili ukupno 702

Aprilskog rata na Me 109, uglavnom iz 6. lovačkog puka: narednik Milivoje Bošković 10 sati, narednik-vodnik Viktor Ulčar 25 sati, kapetan Zlatko Stipčić 32 sata i kapetan Mihajlo Nikolić 50 sati. Stipčić je bio instruktor na preobuci za Me 109 u Šestom puku, a nalet ostvaren u Nemačkoj prilikom njegove preobuke na taj tip aviona ostao je nepoznat. Mihajlo Nikolić je bio u 102. eskadrili koja je posle bombardovanja Bitolja prebačena u Mostar, gde je do Aprilskog rata ostala na redovnom patroliranju. To su razlozi većeg naleta Stipčića i Nikolića.

${ }^{17}$ Божидар Костић, Пламен над Београдом, Београд 1991, 20-22.

${ }^{18}$ L. Deighton, $n$. $d$., svezak prvi, 163.

${ }^{19}$ Милош К. Аћин, Споменица палих Срба ваздухопловаца, „Српска крила“ слободних Срба ваздухопловаца, Вашингтон 1975, 48; Андрија М. Павловић, Сећање на југословенско краљевско ваздухопловство из мирнодопског периода 1919-1941 године, Ваздухопловни гласник, бр. 360, год. XLIII, Лондон, октобар 1991, 25 и 26.

${ }^{20}$ L'Armée de l'Air 1939-1942, Chasse et reconnaisance, Wingmasters Hors Série No 1, Paris 2001, 6 .

${ }^{21}$ Т. К. Милићевић, Краљевско југословенско ваздухопловство пред рат и за време рата 1941. године, Гласник Српског историско-културног друштва „Његош“, свеска 15, јуни 1965, 50.

${ }^{22}$ V. Mikić, Nemačka avijacija..., 23; Greiner/Schramm, $n$. d., 42 и 43. Na 42. strani pod datumom 1. april piše da je , ...dve trećine [nemačkog] ratnog vazduhoplovstva premešteno prema jugoslovenskoj granici“. Na sledećoj strani, pod datumom 6. april, naveden je gotovo upola manji broj upotrebljenih aviona nego što je stvarno bio. 
vazduhoplova u operacijama nad Jugoslavijom. ${ }^{23}$ Njihovi resursi za popunu gubitaka takođe su bili ogromni u poređenju sa jugoslovenskim. Mađarska avijacija je početkom 1941. godine raspolagala sa ukupno 536 letelica, a za dejstva protiv Jugoslavije upotrebila je 287 borbenih aviona. ${ }^{24}$ Protiv ovih snaga stajalo je 950 vazduhoplova jugoslovenske avijacije, 80 iz grčkog i 220 iz britanskog vazduhoplovstva u Grčkoj. ${ }^{25}$ Ukupno, 2401 osovinski vazduhoplov prema 1.250 savezničkih letelica, ili oko $2: 1$ u korist sila Osovine. ${ }^{26}$

Zanimljivu ocenu o Vazduhoplovstvu vojske Kraljevine Jugoslavije dao je komandant nemačke Četvrte vazduhoplovne flote, general-potpukovnik Aleksander Ler, na suđenju u Beogradu 1947. godine: „Otpor jugoslovenske avijacije bio je spretan i vrlo hrabar i ometao je jedinstvenost napada, tako da smo u toku prvog dana rata izgubili $10 \%$ aviona, dok je još $10 \%$ bilo oštećeno... U toku sledećih dana jugoslovenski avijatičari su i dalje pružali vrlo jak otpor. Oni su bili vrlo vešto vođeni i uprkos jakoj nemačkoj nadmoćnosti, uvek su ponovo mogli da se prikupe na pomoćnim aerodromima... Napadi jugoslovenske avijacije na Grac, Bruk na Muri, Bruk na Lajti i Mistelbah u grupama od 2 do 3 dvomotorna bombardera jako su nas ometali iako su štete i gubici bili mali. “27

Najrealniju ocenu o ukupnom uticaju vazduhoplovnih dejstava u Aprilskom ratu dao je novinar švajcarskog lista Revi Militer: ,,... nemačko-italijanski vazdušni udar protiv jugoslovenskog vazduhoplovstva nije bio tako munjevit i sa potpunim uspehom kao u Poljskoj, pošto su jugoslovenski avijatičari još nedelju dana vršili svoje bombarderske zadatke. Međutim, vazdušni napadi na vojne ciljeve u Jugoslaviji postigli su potpun uspeh, jer su sprečili mobilizaciju, koncentraciju i grupisanje jugoslovenske vojske tako da ona nije bila u stanju da pruži jači organizovani otpor, već je prinuđena na bezuslovnu kapitulaciju."

$\mathrm{Za}$ vreme operacija na Balkanu, iznad jugoslovenskog dela Makedonije aprila 1941. godine letelo je i britansko Kraljevsko vazduhoplovstvo (Royal Air Force - RAF), koje je poletalo iz Grčke. Piloti RAF-a prijavili su obaranja nekoliko nemačkih aviona u jugoslovenskom vazdušnom prostoru, ali je prema dokumentima Luftvafe izvesno samo da je jedan obrušavajući bombarder tipa Ju 87B, teško oštećen nad priobaljem Egeja, sleteo na svoje letelište kod Prilepa. ${ }^{29}$ Nešto

${ }^{23} \mathrm{~V}$. Mikić, Italijanska avijacija..., 12.

${ }^{24}$ Csanady-Nagyvarady-Winkler, A Magyar repules törtenete, Muszaki konyvkiadó, Budapest 1977, 230-232; V. Mikić, Nemačka avijacija..., 27.

${ }^{25}$ Огњан М. Петровић, Авиони ваздухопловства војске у априлском рату, Браничево кроз војну и културну историју Србије II, свеска 4, Историјски архив Пожаревац 2007, 374. Navedeno je oko 900 aviona, bez hidroaviona. Greiner/Schramm, $n$. d., 43; V. Terzić, $n$. d., 53.

${ }^{26}$ Zanimljivo je da u nekim svojim razmatranjima Nemci u savezničke snage ubrajaju i jedinice britanskog RAF-a na Malti, kao i one na nosačima aviona, iako su u ovim operacijama u vrlo ograničenom obimu učestvovali samo neki mornarički avioni. U ovom radu oni uglavnom nisu uzeti u obzir.

${ }^{27}$ Vojni arhiv (VA), Beograd, P17, K70a, F1, D1; V. Terzić, $n$. d., 539.

${ }^{28}$ V. Terzić, n. d., 281.

${ }^{29}$ Christopher Shores and Brian Cull with Nicola Malizia, Air war for Yugoslavia, Greece and Crete 1940-1941, Grub Street, London 1987, 244. 
kasnije, još neki nemački aeroplani koji su sleteli u već okupiranu Jugoslaviju bilo je oštećeno u borbama iznad Makedonije ili izgubljeno u udesima. Međutim, gde god da su pali, ovi avioni nisu u okviru teme članaka jer ih nisu napadali pripadnici jugoslovenske vojske i ti gubici nisu nastali u borbenim letovima protiv nas a neki su se dogodili neposredno posle poraza Kraljevine Jugoslavije. Iz istog razloga u ovaj rad uglavnom nisu uključeni nemački gubici nastali prilikom prebacivanja na aerodrome sa kojih se krenulo u napad na Kraljevinu Jugoslaviju, kao ni prilikom odlaska sa Balkana. U razmatranju osovinskih vazduhoplovnih gubitaka nad Jugoslavijom u aprilu 1941. valja takođe imati u vidu i da su jedinice nemačkog Osmog vazduhoplovnog korpusa u Bugarskoj prvih dana istovremeno dejstvovale protiv obe saveznice, a kasnije samo u Grčkoj, tako da nisu svi gubici ove grupacije nastali u letovima protiv Jugoslavije.

Najveće vazduhoplovne bitke vođene su oko Beograda i tu je nastala približno polovina svih nemačkih gubitaka u borbi, najviše zaslugom pilota lovaca Šestog vazduhoplovnog puka, a zatim i protivavionske odbrane grada. ${ }^{30} \mathrm{U}$ drugim delovima Kraljevine Jugoslavije bilo je većih vazduhoplovnih borbi, naročito u okolini Kumanova, Skoplja, Podgorice, Niša, Mostara, Sarajeva i Banja Luke, pa je i tu neprijatelj pretrpeo gubitke. Tokom Aprilskog rata jugoslovensko vazduhoplovstvo imalo je ukupno 1.433 avio-poletanja, od toga 993 leta obavila je lovačka avijacija, 423 bombarderska a 17 izviđačka. ${ }^{31}$ Međutim, to su letovi Operativnog vazduhoplovstva, dok je ukupan nalet Armijskog, Pozadinskog i Pomorskog vazduhoplovstva ostao nepoznat, mada se njihov nalet svakako može meriti sa nekoliko stotina letova. U Jugoslovenskoj kraljevskoj mornarici izuzetno se istakla posada rečnog monitora „Drava“, koji je po broju oborenih nemačkih vazduhoplova bio bolji od nekih protivavionskih ili vazduhoplovnih jedinica. Tu su još i rečni monitor „Morava“ i torpedni čamac „Kajmakčalan“, kao i 76. protivavionski divizion Operativne vojske.

Za većinu nemačkih eskadri iz rata u aprilu 1941. objavljene su knjige o njihovoj istoriji. Kod Italijana je to urađeno samo za neke jedinice, a oni i Mađari objavili su opšte istorije svojih vazduhoplovstava u Drugom svetskom ratu i u okviru toga poglavlje posvećeno Aprilskom ratu. U vazduhoplovnim operacijama protiv Jugoslavije Nemci su imali, trajno ili privremeno, ukupno 98 izgubljenih vazduhoplova (od toga ih 10 nema u zvaničnoj nemačkoj evidenciji, ali za mnoge među njima sačuvani su njihovi ostaci ili drugi tragovi) ${ }^{32}$ i 37 oštećenih aviona 1995, 32 и 33.

${ }^{30}$ Небојша Ђокић, Свим снагама на град, Војска, бр. 137, год. IV, Београд, 23. март

31 Андрија Павловић, За историју, Југословенско ваздухопловство у априлском pamy 1941. године, Ваздухопловни гласник, бр. 348, год. XL, Лондон, август 1988, 21 и 29.

${ }^{32}$ C. Shores et al, $n$. d., 311. - Šorz navodi da su u aprilu 1941. nad Jugoslavijom i Grčkom, prema nemačkim izvorima, izgubljena ukupno 182 aviona (u kategoriji oštećenja od 60 do $100 \%$ ), od toga 164 u borbi a oko 50 u operacijama iznad Jugoslavije. Međutim, autor ovog članka je u listi gubitaka, koju je publicista Boris Ciglić sačinio kao izvod iz nemačkih mikrofilmova, samo za period Aprilskog rata izbrojao 70 izgubljenih nemačkih aviona, u istoj kategoriji oštećenja, tokom operacija protiv Kraljevine Jugoslavije. 
(od kojih samo za jednog nije nađena potvrda u nemačkim dokumentima), Italijani 12 letelica (od toga 5 nije nađeno u njihovoj arhivi), kao i 22 oštećena aviona (od kojih je u ovom pregledu pobrojano 12), a Mađari su imali 5 izgubljenih aviona i više prinudno sletelih aeroplana tokom operacija od kojih su tri nepovratno izgubili nekoliko dana po završetku Aprilskog rata.

Sastav oštećenih i izgubljenih aparata je sledeći: 38 jednomotornih obrušavajućih bombardera Ju 87 varijante B i R, 27 srednjih dvomotornih bombardera Ju 88 varijante A i D, 1 srednji dvomotorni bombarder He 111, 13 dvomotornih lakih bombardera Do 17 varijante $\mathrm{P}$ i Z, 2 jednomotorna laka dvokrilna obrušavajuća bombardera Hs 123A, 10 lakih jednomotornih izviđača Hs 126B, 1 laki jednomotorni transportni avion $\mathrm{Ju} \mathrm{V} \mathrm{34,} 8$ velikih tromotornih transportnih aviona Ju 52,35 jednomotornih lovaca $\mathrm{Bf} 109 \mathrm{E}, 13$ dvomotornih teških lovaca $\mathrm{Bf} 110$ varijanti C i D, 1 jednomotorni lovac G 50bis, 2 jednomotorna lovea MC 200, 2 jednomotorna dvokrilna izviđača Ro 37bis, 1 dvomotorni bombarder BR 20, 5 tromotornih bombardera $Z$ 1007bis, 3 jednomotorna dvokrilna lovca CR 42, 1 jednomotorni dvokrilni lovac CR 32 i 1 tromotorni transportni avion S 75. Najviše mašina čiji gubitak za sada nije potvrđen u neprijateljevoj zvaničnoj arhivi pripada tipu Ju $87 .^{3.3}$

U pregledu sopstvenih gubitaka, suprotna strana uračunava i ono što je nastalo pre i posle Aprilskog rata. To je naročito karakteristično za nemačku Luftvafe koja je za napad na Jugoslaviju mnoge jedinice prebacila iz Francuske pa čak i iz Afrike. Poslednji datum ove kampanje u tim izveštajima zavisi od toga do kada su se one zadržale na polaznim ili jugoslovenskim aerodromima. Tako, nemačke vazduhoplovne jedinice svoje izveštaje iz rata protiv Jugoslavije uglavnom počinju 28. marta a završavaju najčešće do 15 . aprila, kada se prebacuju dalje ili preusmeravaju svoja dejstva protiv Grčke. Neke daju zbirne izveštaje u kojima sumiraju operacije protiv obe zemlje. Pojedini od tih izveštaja završavaju i sa datumom posle kapitulacije Kraljevine Jugoslavije. U toku preleta na nove aerodrome u jugoslovenskom okruženju i vežbanja u letu radi upoznavanja novog terena takođe su izgubljeni neki avioni. Odmah po završetku operacija protiv Kraljevine Jugoslavije, na okupiranim jugoslovenskim aerodromima i drugde izgubljeni su neki vazduhoplovi koje neprijatelj takođe uračunava među gubitke nastale u operacijama protiv Jugoslavije. Iako su ovim radom uglavnom obuhva-

${ }^{33}$ Peter C. Smith, Stuka Squadron, Stukagruppe 77 - The Luftwaffe's 'Fire Brigade', I Stuka 77, Patrick Stephens Ltd, Northamptonshire, 1990, 93. - U ovom delu spominje se samo gubitak od 42 poginula letača na avionima Ju 87 u operacijama protiv Jugoslavije, Grčke i ostrva Krit, bez razgraničenja koliko pripada svakoj od pomenutih oblasti i jedinica naoružanih ovim avionom. Međutim, nije navedeno koliko je bilo ranjenih a koliko oborenih a nepovređenih letača. Knjiga je većinom posvećena Prvoj grupi štukagešvadera 77, ali se u njoj ne spominje nijedan gubitak iz ove jedinice u sukobima nad Jugoslavijom aprila 1941. iako o njima ima podataka u nemačkoj arhivi i u drugim knjigama; Holger Nauroth, Stukageschwader 2 Immelmann, 1. auflage, Verlag K. W. Schütz, Preussich Oldendorf 1988, 138. U ovom izdanju, mada je dat hronološki pregled dejstava protiv Jugoslavije, nije spomenuto bilo koje naseljeno mesto kao meta napada a takođe nijedan gubitak i pored toga što podataka o njima ima u drugim izvorima. 
ćeni samo gubici nastali tokom Aprilskog rata ovde pominjemo i tu vrstu gubitaka, kao dodatnu ilustraciju težine zadatka pred kojim su se našla osovinska vazduhoplovstva u aprilu 1941. godine. Ukupno je na taj način trajno ili privremeno izgubljeno (izbačeno iz stroja) oko 50 osovinskih vazduhoplova. ${ }^{34}$

Formulacija gubitaka u nemačkim dnevnim saopštenjima za javnost zaslužuje posebnu pažnju. Nemci navode samo ,avione koji se nisu vratili u svoje baze“, ali je i među povratnicima bilo onih sa većim oštećenjima. U načelu, vazduhoplovi sa oštećenjem preko $60 \%$ su prema normama nemačke vazduhoplovno-tehničke službe predlagani za otpis, mada su mnogi od njih kasnije ipak popravljeni (nekad krpljeni iz delova više aviona). Ni izveštaji tehničke službe Luftvafe pri njihovom generalštabu ne sadrže podatke o svim izgubljenim avionima, ali su neki nađeni, na nižem nivou komandovanja, u arhivi jedinica koje su učestvovale u napadu na Jugoslaviju. Ove razlike primećuju i strani autori. ${ }^{35}$ Kratko ostajanje na pojedinim aerodromima, odnosno česte selidbe, takođe mogu biti uzrok ovoj neažurnosti. ${ }^{36}$

${ }^{34}$ Bundesarchiv Militärarchiv, Freiburg im Breisgau (dalje: BA MA), Film RL 2/III. 753/118/4; $753 / 176 / 2 ; 753 / 178 / 9 ; 753 / 178 / 10 ; 753 / 182 / 14 ; 753 / 180 / 15 ; 753 / 181 / 16,756 / 255 / \mathrm{s} ; \quad 753 / 178 / 8$; $753 / 178 / 11 ; 753 / 218 / 28 ; 753 / 218 / 29 ; 753 / 184 / 3 ; 753 / 194 / 8 ; 753 / 194 / 9 ; 753 / 194 / 10 ; 753 / 194 / 11$; 753/185/17; 753/241/34; 753/190/15; 753/194/3; 753/190/14; 753/195/17; 753/194/4; 753/216/16; 753/241/29; 753/261/19; 753/253/11; 753/272/44; 753/314/27; Wolfgang Dierich, Kampfgeschwader 51 „Edelweiss“, Eine Chronik aus Dokumenten und Berichten 1937-1945 (dalje: KG 51..), 4. überarbeitete und ergänzte Auflage, Motorbuch Verlag, Stuttgart, 1975, 141; Wolfgang Dierich, Kampfgeschwader ,Edelweiss “ - The History of the unit 1939-1945 (dalje: Еделвајс..), Ian Allan, London 1975, 53; J. Prien et al, Die Jagdflieger..., 240, 245, 255; М. Стојнић, н. ч., 141.

${ }^{35}$ Erik Mombeek, Jean-Louis Roba \& Martin Pegg, Jagdwaffe, Strike in the Balkans (dalje: Jazдвафе...), April-May 1941, Luftwaffe Colours, Volume Three Section 1, Ian Allan Publishing Ltd, Hersham 2002, 49. - Uprkos boljoj popuni gubitaka nego kod njihovih protivnika, ni to nije bilo dovoljno pa se pribeglo kanibalizaciji neispravnih aviona odnosno skidanju ispravnih delova radi njihove ugradnje na druge avione, što je dodatno smanjilo nemačke snage. Pojedine nemačke lovačke vazduhoplovne grupe su umesto 40 aviona na kraju balkanske kampanje imale svega 6 do 9 ispravnih i borbeno sposobnih vazduhoplova, što bi jedva odgovaralo jednoj eskadrili. Međutim, uprkos izvesnoj začuđenosti stranih autora nad ovakvim gubicima, oni su potpuno u skladu sa nemačkom doktrinom Blickriga (munjevitog rata) prema kojoj je i visoka stopa gubitaka prihvatljiva ako se rat dobije u kratkom roku. $U$ to vreme preostali nemački protivnici na Mediteranu su bili samo na Gibraltaru i sredozemnim ostrvima: Malta i Krit, kao i u severnoj Africi.

${ }^{36}$ VA, National Archive Washington (NAW), NT 501-251-551. - Nemački oficir određen da se brine za pronalaženje i pokop nesahranjenih pripadnika nemačke oružane sile, kao i prenos posmrtnih ostataka privremeno pokopanih (Wehrmacht gräber offizier), oberlojtnant Šrej, žalio se u svom izveštaju br. 5 od 10. oktobra 1941. da mu nemačke vazduhoplovne jedinice još uvek nisu dostavile nikakve podatke o svojim gubicima prilikom borbenih dejstava nad Jugoslavijom u aprilu 1941. One su tada već uveliko bile na drugim ratištima. - Lynn Ritger, The Messerschmitt Bf 109, Part 1: Prototype to 'E' Variants, SAM Publications, Bedford 2006, 87. - Pozadinske jedinice Luftvafe, na primer čete za vezu koje su putovale železnicom ili drumom, tokom balkanske kampanje nisu uspevale da stignu matične letačke jedinice zbog brzog napredovanja nemačke vojske. One će se ponovo spojiti tek po završetku ovih operacija. U takvoj situaciji ažurno vođenje administracije bilo je teško. Ritger navodi da je od približno 90 izgubljenih aviona Bf 109 tokom aprila i maja 1941. uspeo da prikupi osnovne podatke samo za oko 20 vazduhoplova ovog tipa. 
Avijacija sila Osovine, privremeno ili trajno, u borbama nad Kraljevinom Jugoslavijom gubila je aparate: 1 . aprila - jedan avion, 6 . aprila -80 aviona, 7. aprila -27 aviona, 8. aprila - šest vazduhoplova, 9. aprila - pet, 10. aprila - jedan, 11. aprila - tri, 12. aprila - 13, 13. aprila - 10, 14. aprila - 10 aviona, 15. aprila - četiri, 16. aprila - tri i 17. aprila - jedan avion. Kao poređenje, na dan 15. avgusta 1940. u bitci za Britaniju, nemačko vojno vazduhoplovstvo izgubilo je, po sopstvenim podacima, 55 aviona. ${ }^{37} \mathrm{U}$ nemačkom saopštenju najveći dnevni gubitak tokom balkanskih operacija bio je prvog dana rata i on iznosi 32 aviona koji se nisu vratili u bazu. ${ }^{38}$ Nad Jugoslavijom je, prema istom izvoru, izgubljen 21 vazduhoplov (i još dva italijanska) a drugog dana rata 7 nemačkih i 2 italijanska aviona. ${ }^{39}$ Međutim, i u ono vreme postojali su nešto drukčiji javni podaci, pretežno iz štampe. Nemački vojni časopis Militer Vohenblat od 28. aprila 1941. u članku „Razmatranje napada na Jugoslaviju“ donosi kritiku članka objavljenog u švajcarskim novinama Cirih Tagblat, koji se odnosi na gubitke nemačke avijacije iznad Beograda. Po švajcarskim podacima Nemci su izgubili, 6 . aprila - 32 vazduhoplova dejstvom jugoslovenske avijacije i 15 od protivavionske artiljerije; a 7. aprila - 15 letelica od jugoslovenske avijacije i 10 od protivavionske artiljerije. Militer Vohenblat tvrdi da je izgubljeno ukupno 50 aviona, od toga 40 iznad Beograda. ${ }^{40}$ Glavni obaveštajni centar 1. vazduhoplovne zone u Beogradu registrovao je 40 obaranja u prva dva dana, a od toga je protivavionskoj artiljeriji pripisano $25 .^{41}$ Međutim, komandant Teritorijalne vazdušne odbrane, divizijski general Teodosije Luković, u svojim sećanjima iz 1953. godine iznosi da je prvog dana rata vazdušna odbrana Beograda (tačnije protivavionska artiljerija) prijavila obaranje 25 neprijateljevih aviona što je po njegovoj oceni preterano, ali (iz druge ruke) navodi mišljenje nemačkog vazduhoplovnog oficira da je dejstvo jugoslovenske protivavionske artiljerije bilo bolje nego poljske ili britanske. ${ }^{42}$ Prvog dana rata jugoslovenskim pilotima lovačkih aviona u operacijama nad Beogradom pripisana su 32 oborena aviona a sledećeg dana, po jugoslovenskim podacima, neprijatelj je izgubio 14 letelica. ${ }^{43}$

\footnotetext{
don $1987,117$.

${ }^{39}$ VA, P17, K37, F1, D14, L9 и 5; V. Terzić, $n$. d., 294 и 322. - Nemačka vrhovna komanda (OKW) u izveštaju za 7. april navodi gubitak od 7 sopstvenih aviona, a Glavna komanda nemačkog ratnog vazduhoplovstva (ObdL) samo dva vazduhoplova.

${ }^{40}$ VA, P17, K9, F1, D40, L18. - Visoka podudarnost brojki iz švajcarskih novina sa jugoslovenskim podacima, naročito za prvi dan rata, navodi na pomisao da je izvor novinskog teksta možda bio jugoslovenski. Iako je u ondašnjoj inostranoj štampi objavljeno više članaka u kojima se navode i veći nemački gubici, štampa Trećeg rajha osvrnula se, koliko je poznato, samo na tekst objavljen u listu Cirih Tagblat.

${ }^{41}$ Šime I. Oštrić and Čedomir J. Janić, IK Fighters (1930-40s), Profile publications Ltd, No 242, Berks, 1972, 189; Dragan Kljakić, Oni su branili Beograd, August Cesarec, Zagreb 1980, 51. Prema izjavi potpukovnika Srđana Krmpotića, komandanta vazdušne odbrane Beograda.

${ }^{42}$ VA, P17, K9, F1, D39, L15.

${ }^{43}$ Б. Костић, н. $\partial, 83,95,108,112,134$.
}

${ }^{37}$ L. Deighton, $n$. d., svezak drugi, 78.

${ }^{38}$ Karl Ries, The Luftwaffe a Photographic Record 1919-1945, B. T. Batsford Ltd, Lon- 
Gubici u ljudstvu, koliko se uspelo u identifikaciji kroz zvanična dokumenta, iznosili su 228 ljudi:

- Nemci su imali 86 poginulih (17 oficira, 52 podoficira i 17 vojnika i ostalih) $)^{44}, 45$ ranjenih (11 oficira, 30 podoficira i 4 vojnika i ostalih), 29 nestalih (5 oficira, 20 podoficira i 4 vojnika) a 12 zarobljenih (4 oficira i 8 podoficira). Ukupno 172 vojna lica, od kojih 16 nisu vazduhoplovci nego pripadnici Vermahta. ${ }^{45}$

- Italijani - 17 poginulih (4 oficira, 5 podoficira, 3 vojnika i 5 za koje nisu utvrđena zvanja i činovi), 2 ranjena i 4 zarobljena ( 1 oficir, 1 podoficir i 2 vojnika). Ukupno 23 vazduhoplovca.

- Mađari - 24 poginula (3 oficira, 3 podoficira i 18 padobranaca) i 9 povređenih (po 1 oficir i podoficir i 7 vojnika). Ukupno 33 vazduhoplovca.

Što je viši nivo komandovanja to su veće razlike u dokumentima koja se odnose na isti događaj. Primer je avion Ju 88A (kodna oznaka 9K+FS, fabrički broj 6224) iz III/KG 51, za koga je u ratnom dnevniku matične jedinice, u posebnom izveštaju posade, bez navođenja koda, dat opis u kome se jasno navodi da je tokom borbenog leta napadnut i teško oštećen (pogodak u levi motor) od jugoslovenskog lovca Me-109 koji je otvarao vatru na njega. Jedan član posade je poginuo a dva su ranjena. Kako je ovo bio jedini izgubljen avion u tom letu, registracija (kod) je potvrđen u dnevniku letenja jedinice. Na nivou Glavne komande nemačkog vazduhoplovstva, u dnevniku gubitaka, u delu koji se odnosi na isti avion uopšte nije pomenut napad jugoslovenskog aparata a za ovaj potpuni gubitak $(100 \%)$ navodi se da je rezultat prinudnog sletanja u Aradu usled otkaza motora (sic!). Za neke oborene ili poginule nemačke pilote lovce utvrđeno je da su žrtve jugoslovenskih pilota lovaca, a u izveštajima nemačkih viših komandi navodi se kao razlog gubitka vatra sa zemlje. Pojedini vazduhoplovi izgubljeni u okršajima iznad Jugoslavije nisu pronađeni u zvaničnoj nemačkoj arhivi, ali jesu u dokumentima italijanskog i mađarskog porekla, ili su čak sačuvani i neki njihovi delovi ili drugi tragovi.

Veliki problem predstavlja gotovo potpuno odsustvo bilo kakvih zvaničnih jugoslovenskih dokumenata, koji nisu grupisani, a najčešće se svode na raporte ili sećanja očevidaca pisana posle mesec dana ili više godina, sada uglavnom pohranjene u Vojnom arhivu u Beogradu. Na njih su veoma često uticale

${ }^{44}$ C. Shores et al, $n$. d., 309 и 311. - Na 309. strani ovi autori spominju 192 pripadnika Luftvafe poginula ili ranjena tokom napada na Grčku, a na 311. piše da je Luftvafe aprila 1941. u avionima sa većim oštećenjem (60-100\%) izgubila 150 oficira i 42 podoficira (mrtvi ili nestali), u operacijama protiv Jugoslavije i Grčke.

${ }^{45}$ Pored pomenutih u ovom radu, još jedan pripadnik Luftvafe je poginuo 13. aprila u Mađarskoj. To je feldvebel Vilhelm Šnajder iz nemačke vazduhoplovne jedinice 2/KG 51 za koga nikako nisam uspeo da odredim čiji je član posade. - W. Dierich, $K G 51 \ldots, 269$. U ovaj broj nije uračunato 10 likvidiranih nemačkih diverzanta, ubacivanih padobranom u Šumadiju; Mihailo Marić, ,, Uništiti Jugoslaviju! “, Hitler i nemački generali u aprilskom ratu 1941, Beograd 1984, 244 . Iz firerovog Glavnog stana nemačka Vrhovna komanda iznela je sledeće podatke o gubicima Luftvafe u operacijama protiv Jugoslavije i Grčke: poginulo - 15 oficira i 84 podoficira i vojnika; nestalo - 40 oficira i 123 podoficira i vojnika; ranjeno - 25 oficira i 124 podoficira i vojnika. 
trenutne političke prilike, kako ratne tako i posleratne, pa pojedina svedočenja nisu sasvim verodostojna. Neki jugoslovenski zvanični raporti u kratkotrajnom sukobu nisu ni napisani, a deo jugoslovenske vazduhoplovne arhive zaplenili su Nemci dok su deo uništili Jugosloveni, nešto u toku rata, manje po njegovom završetku. Još uvek nisu pregledane jugoslovenske izjave pisane u zarobljeništvu i dostavljene Crvenom krstu u Ženevi gde se nalaze i danas. U njima je pored osnovnih podataka bio i ratni raspored i kratak opis ratnog puta podnosioca izjave. Bez ovih izjava zarobljenici nisu mogli biti uvedeni u zvanične zarobljeničke spiskove niti primati pakete od kuće i zato su se svi potrudili da ih napišu. ${ }^{46}$ Osnovu izvora prvog reda predstavljaju dokumenta suprotne strane. To može stvoriti jednostran pogled na te događaje. Zato su odstupanja, nejasnoće i suprotnosti u mnogim detaljima iz različitih izvora uobičajeni.

Ideološkom isključivošću i neumerenim veličanjem narodnooslobodilačke borbe u vreme komunističkog režima stvoreno je čudno stanje da se javnost ponosila svojim vazduhoplovcima koji su branili Beograd i druga mesta, a sami posleratni vazduhoplovci kao da su zazirali od njihovog primera. ${ }^{47}$ Druga strana medalje, za istraživače ništa povoljnija, bila je neumereno slavljenje i izmišljanje nepostojećih pobeda u vazduhu u domaćoj štampi i publicistici usled nepoznavanja događaja. Tako je bilo i sa pobedama pilota Milutina Grozdanovića. U feljtonu Milorada Jankovića napisano je da je postigao dve pobede u vazduhu. ${ }^{48}$ Nešto kasnije, u istim novinama, pojavio se novi feljton Đorđa Milanovića, gde je navedeno da je kapetan Grozdanović oborio tri nemačka bombardera. ${ }^{49}$ Kada sam pre više od dve decenije lično upoznao Grozdanovića, upitao sam ga šta je istina. On mi je odgovorio da je uvek pričao samo o dva nemačka aviona. Posle toga, vazduhoplovni publicista Milan Micevski otišao je u uredništvo lista „Politika“ $i$ isto pitanje postavio uredniku rubrike. On mu je odgovorio da je Grozdanović invalid pa su se u redakciji sažalili i dodelili mu jednu pobedu više. O netačnostima u feljtonu razgovarao je sa Milanovićem vazduhoplovni publicista Šime Oštrić. Milanovićev stav bio je da on ne piše istoriju nego feljtone. Dodatnu težinu njegovom mišljenju davala je činjenica da je on tada bio aktivni oficir Jugoslovenskog ratnog vazduhoplovstva, pa su neupućeni podrazumevali da je a priori stručan za ono o čemu piše. Nažalost, u tim vremenima tako je razmišljala većina pisaca koji su se ovim bavili, među kojima su neki bili i sa titulom magistara ili doktora nauka. Vladajući režim je pod pritiskom javnosti dozirano puštao informacije u medije, a pojedinci koji su se bavili ovom temom ponekad su

\footnotetext{
${ }^{46}$ Iz razgovora autora sa profesorom Boškom Kusakovićem, 2003.

47 Чедомир Јанић, Критеријуми за вредновање традииија, 34, у: Вредновање ваздухопловних традиција, Београд 1994.

48 Милорад Јанковић, фељтон: Априлски рат (61. наставак), Јунаци одбране Београда, Политика, бр. 21428, год. LXX, Београд, 2. јун 1973, 19.

49 Ђорђе Милановић, фељтон: Асови у ваздушном рату (39. наставак), Шпијуни у манастиру, Политика, бр. 22642, год. LXXIII, Београд, 17. октобар 1976, 17.
} 
imali problema. ${ }^{50}$ Drukčije shvatanje zvaničnika počelo je tek sa političkim promenama u društvu početkom 90-ih godina prošlog veka. U poslednjoj deceniji, međutim, kao da jenjava zanimanje javnosti za ovu temu, što nije samo rezultat protoka vremena i činjenice da više skoro i nema živih učesnika ovih događaja, nego i sadašnje opšte političke klime. ${ }^{51}$ Trebalo bi podsetiti da, iako je i ranije postojao predlog da se vazduhoplovci Aprilskog rata odlikuju, to je prvi učinio vođa slobodnih Francuza general Šarl de Gol 1943, a Otadžbina tek 2002. godine. $^{52}$

U ovim istraživanjima, (ne)razlikovanje vrsta (tipova) i namene letelica vrlo je važno jer mnoge greške potiču upravo odatle. ${ }^{53}$ Bitno je i to da su tada lokalna vremena u Austriji (kao delu Trećeg rajha), Albaniji (okupiranoj od Italijana), Italiji i Mađarskoj (od 8. aprila) bila ista kao u Jugoslaviji, a u Bugarskoj i Rumuniji išla unazad za jedan sat.

Rat sa NATO 1999. godine iako je duže trajao, u vazduhoplovnom pogledu podseća na rat u vazduhu iznad Kraljevine Jugoslavije, aprila 1941: potpuno opkoljavanje i dejstva iz svih pravaca, sličan odnos snaga u raspoloživim letelicama, nedovoljan nalet jugoslovenskih pilota, njihovo neiskustvo kao i heroizam. $^{54}$

Struktura gubitaka obe strane prilično je poznata i moguće ih je uporediti. Grčke, italijanske i britanske vazdušne snage bile su u ratu na Balkanu još od

${ }^{50}$ Koliko je bilo šta u vezi sa Kraljevinom Jugoslavijom tada bilo nepodobno pokazuje i slučaj dokumentarnog filma „Kada se nebo crnelo nad Beogradom“. Na traženje generala Ilije Perišića, tadašnji kustos Muzeja Jugoslovenskog ratnog vazduhoplovstva, istoričar Čedomir Janić, morao je da povuče svoje ime sa špice filma i ostavi samo naziv institucije u kojoj je radio. Iste godine ovaj film je dobio nagradu Saveza boraca narodnooslobodilačkog rata (SUBNOR).

${ }_{51}$ Ђорђе Станковић, Право на памћење - немачко убијање Београда 1941. године (научни есеј), Војно-историјски гласник, бр. 1, Београд 2008, 153-177.

${ }_{52}$ Branko Petranović, Srbija u Drugom svetskom ratu 1939-1945, Beograd 1992, 167; Б. Костић, н. д., 113; Из војног кабинета председника СРЈ, Постхумно одликовани војници и офииири, Признања и за исказану храброст у априлском рату 1941, Политика, бр. 31766, год. ХСІХ, Београд, 1. април 2002, 6; Председник СРЈ посмртно одликовао хероје, Признаьа за храброст у НАТО агресији и Априлском рату 1941, Политика, бр. 31845, год. ХСІХ, Београд, 3. јул 2002, А7.

${ }_{53}$ Karl Gundelach, Kampfgeschwader 4 General Wever, Eine Geschichte aus Kriegstagebüchern, Dokumenten und Berichten 1939-1945, 1. auflage, Motorbuch Verlag, Stuttgart, 1978, 126-128. - Na jugoslovenskoj strani se najčešće greši kada se spominju nemački bombarderi He 111. Međutim, samo je jedna nemačka vazduhoplovna jedinica u napadu na kraljevinu Jugoslaviju, II/KG 4 General Vefer, bila njime opremljena. U knjizi nema ni nagoveštaja o bilo kakvom gubitku nad Jugoslavijom aprila 1941. Pod Hajnkelima 111 Jugosloveni su najčešće podrazumevali Ju 88 ili Do 17. Često se spominju i lovci Bf 109F. Meseršmitov avion, ove tada najnovije varijante, po otklanjanju nedostataka tek je počeo da se masovno uvodi u naoružanje Luftvafe kada je započeo napad na Jugoslaviju. Prema elektronskoj poruci istraživača Kristijana Kirša iz Berlina, upućenoj Borisu Cigliću 14. maja 2001, u aprilskim listama isporuka aviona Bf 109 nema varijante $\mathrm{F}$ ni u jednom primerku u jedinicama koje su tada letele nad Jugoslavijom.

${ }^{54}$ М. Хреља, Б. Димитријевић, н. д., 6. - Sa braniocima Beograda 1999. godine posle rata sa NATO sreli su se branioci iz 1941: Mihajlo Nikolić i Đorđe Stojanović. - Miladinović Predrag, In memoriam, Đorđe Stojanović (1911-2001), Naša krila, br. 35, god. IX, Beograd, septembar 2001, 14. 
prethodne godine, a Nemci su posle zauzimanja Grčke u aprilu 1941, narednog meseca izvršili vazdušno-desantnu operaciju protiv grčko-britanskih snaga, kojom su zauzeli ostrvo Krit. Radi poređenja sa jugoslovenskim vazduhoplovstvom ovde su predstavljeni samo opšti vazduhoplovni gubici svih zaraćenih strana u aprilu 1941. na Balkanu. ${ }^{55}$ RAF-ovi piloti prijavili su ukupno 26 vazdušnih pobeda i 17 verovatnih (oštećenih aviona), dok su njihovi grčki saborci oborili 7 neprijateljevih aviona. U isto vreme saveznička protivavionska artiljerija u Grčkoj prijavila je obaranje 12, a oštećenje jednog aviona. ${ }^{56}$ Italijani su prijavili obaranje 5 jugoslovenskih aviona i jednog verovatno, a nad Grčkom 6 savezničkih aviona i 5 verovatno ${ }^{57}$ Nemački letači su prijavili ukupno 110 pobeda u vazduhu, od toga 58 nad Jugoslavijom (Šorz u svojoj knjizi navodi 30-40), a nemačka protivavionska artiljerija prijavila je 9 oborenih jugoslovenskih letelica. ${ }^{58}$ Mađarska protivavionska artiljerija prijavila je obaranje pet jugoslovenskih aviona. $^{59}$

${ }^{55}$ Pregledom različitih dokumenata i izjava uočili smo prijave obaranja za 16 sopstvenih aviona od strane jugoslovenskih protivavionaca, ali za najmanje polovinu njih je proverom utvrđeno da nisu tačne. Za sada je poznato da su saveznici u Grčkoj, aprila 1941, greškom oborili jedan jugoslovenski avion kod Soluna.

${ }^{56}$ C. Shores et al, $n$. d., 230-311. Treba imati u vidu i različit način priznavanja vazdušnih pobeda: kod Britanaca je priznanje deljeno na jednake delove među pilotima koji su oborili isti avion pa kod njih imamo i 1/4, 1/3 ili 1/2 vazdušne pobede. Autor ovog članka je takve gubitke neprijatelja računao na isti način kao u drugim vazduhoplovstvima, kao jednu pobedu, bez ponavljanja iste. Pored toga, Britanci su oštećene avione sa nepoznatom konačnom sudbinom imenovali kao verovatno oborene. Ni Britanci nemaju svu arhivu svojih jedinica jer nisu uspeli da je potpuno evakuišu, o čemu svedoči i faksimil dokumenta koji su Nemci zaplenili od Britanaca, objavljen u Šorzovoj knjizi na str. 284; A. Papagos, Grčka u ratu 1940-1941, 353. Prema Papagosu Grci su oborili ukupno 17 nemačkih aviona.

${ }^{57}$ Giuseppe Santoro, L'Aeronautica Italiana nella Seconda Guerra Mondiale, Volume Primo, Edizione ESSE, Milano-Roma, drugo izdanje, 1966, 216; C. Shores et al, n. d., 230-311.

${ }^{58}$ C. Shores et al, n. d., 230-311; J. Prien et al, Die Jagdflieger..., 187, 202, 245, 263, 275, 293, 311, 339, 370; Heinz J. Nowarra, Messerschmitt Bf 109, Aircraft \& Legend, Haynes, Nr. Yeovil 1989, 124; Krzystof Janowicz, Bałkany 1941, AJ Press, Gdynia 1996, 26, 56. - Poznati nemački vazduhoplovni istoričar Novara izneo je tvrdnju kako su u balkanskoj kampanji nemački piloti - lovci oborili ukupno 167 britanskih, grčkih i jugoslovenskih aviona, uz gubitak od svega 20 jednomotornih lovaca Bf109. Poljski autor dodaje još i 417 savezničkih aviona uništenih na zemlji dejstvom protivničke avijacije (po Šorzu: bez Krita ukupno 246 letelica od toga oko 140 britanskih i grčkih), od toga preko 150 jugoslovenskih, uz 57 oborenih jugoslovenskih vazduhoplova. Međutim,to se odnosi na sve operacije u balkanskoj kampanji: Poduhvat 25 (Unternehmen 25 - napad na Jugoslaviju), operaciju Marita (Unternehmen Marita - napad na Grčku) i operaciju Merkur (Unternehmen Merkur - napad na ostrvo Krit) tokom aprila i maja 1941. Prema najnovijim istraživanjima nemačkih autora (J. Prien et al, Die Jagdffieger...), u aprilu 1941. nemački letači na ovom tipu aviona prijavili su ukupno 83 obaranja savezničkih aviona na Balkanu (od toga je 45 jugoslovenskih aviona plus jedan koga je oborio nemački avion iz lovačke škole u Beču), a privremeno ili trajno je tokom istog meseca izgubljeno 106 nemačkih vazduhoplova Bf-109 (od toga samo 14 u vazdušnoj borbi i 16 od protivavionske vatre). Još 9 oborenih jugoslovenskih vazduhoplova prijavili su letači na teškim dvomotornim lovcima Bf 110 (razaračima, po tadašnjoj nemačkoj vazduhoplovnoj terminologiji), a preostala tri oborena su mitraljeskom vatrom sa nemačkih bombardera u letu.

${ }^{59}$ C. Shores et al, n. d., 212; М. Стојнић, н. ч., 138-139. 
Jugoslovenska protivavionska artiljerija prijavila je više desetina oborenih neprijateljevih vazduhoplova, a identifikovano je 45 prijava obaranja (30 protivavionske jedinice, 7 mornarica i 8 kopnena vojska) i još 16 pogođenih letelica. Od toga je u neprijateljevoj arhivi nađena potvrda za 32 oborena i 14 oštećenih vazduhoplova. U posleratnim istraživanjima jugoslovenskim letačima pripisano je oko 70 uništenih neprijateljskih vazduhoplova (od toga 6 sa bombardera), a za 31 oborenog i 16 oštećenih nađena je potvrda u neprijateljevim dokumentima. Preostalih oko 70 osovinskih vazduhoplova izgubljeno je u udesima: na poletanju ili sletanju, sudarima sa drugim avionima u vazduhu ili na zemlji ili iz drugih razloga (tehnički otkaz). ${ }^{60} \mathrm{Na}$ neke od ovih gubitaka dodatno su uticale i loše vremenske prilike.

Nadmoćnost neprijatelja u ljudstvu i tehnici, uz superiornu taktiku i strategiju, ostavljala je vazduhoplovnim snagama branioca ograničenu mogućnost za povlačenja na nove aerodrome. ${ }^{61}$ Suprotno tome, Nemci su zahvaljujući kružnoj osnovici za napad mogli da manevrišu kako su hteli. Loše vreme za letenje zato je više smetalo saveznicima i radi toga je više stotina savezničkih aviona ostavljeno, a mnogi među njima su uništeni od strane svojih posada kako ih ne bi iskoristio protivnik. Ovo su, uz avione izgubljene na zemlji tokom napada neprijateljeve avijacije, najveći gubici savezničke avijacije i oni su, pored gubitka teritorije, presudno doprineli slamanju njihovog otpora, dok takvih gubitaka na suprotnoj strani gotovo da nije bilo. ${ }^{62}$ Jugoslovenska avijacija nije upotrebljena u sadejstvu sa suvozemnim trupama već kao samostalna udarna snaga protiv nadirućeg neprijatelja. Jasno je da se posle tih udara neprijatelj sređivao i nastavljao svoj zadatak, jer ga sama avijacija koja je raspolagala tako malim snagama nije mogla zadržati. $^{63}$

Prema nemačkom ratnom izveštaju, njihovo vazduhoplovstvo je 6 . aprila oborilo 38 jugoslovenskih aviona i još 77 uništilo na zemlji a dva je oborila protivavionska artiljerija. Drugog dana rata nemački avioni su u vazdušnim borbama oborili 22 jugoslovenska i uništili još 34 vazduhoplova na zemlji. Sledeći gubici naneti Jugoslovenima su, po istom izvoru, uglavnom u avionima uništenim na zemlji: 9. aprila jedna letelica i 10 oštećenih na zemlji kao i tri oborena vazduhoplova, 10. aprila jedan aeroplan, 11. aprila 10, 12. aprila 41 i 6-10 oštećenih, 13.

${ }^{60} \mathrm{Na}$ neke od ovih aviona istovremeno su pucali i protivavionci i piloti, pa je ukupan broj neprijateljevih vazduhoplova izgubljenih zbog neposrednog borbenog dejstva Jugoslovena nešto manji.

${ }^{61}$ Jugoslovenski letači većim delom nisu bili obučeni za letenje u složenim meteorološkim uslovima i noću. Njihova letelišta i vazduhoplovi često nisu bili odgovarajuće opremljeni za takve letove. Za razliku od jugoslovenskih letača, Nemci nisu bili opterećeni ratnim imperativom da se mora leteti i u takvim uslovima. Otuda potiče deo gubitaka nastao usled lošeg vremena. Jugoslovensko vazduhoplovstvo nije izvršilo oko $50 \%$ ratnih zadataka zbog nevremena (magla, sneg i kiša). - V. Terzić, $n$. d., 525.

${ }^{62} \mathrm{~V}$. Terzić, $n$. d., 525 i 539. Jugoslovensko vazduhoplovstvo izgubilo je $45 \%$ svoje avijacije na letelištima i aerodromima zbog kiše i snega koji su raskvasili ratna letelišta sa zatravljenim pistama posle čega je poletanje bilo nemoguće.

${ }^{63}$ V. Terzić, n. d., 524. 
aprila sedam letelica. ${ }^{64} \mathrm{Uz}$ ono što su prijavili Italijani i Mađari, to je oko 270 jugoslovenskih vazduhoplova uništenih direktnim borbenim dejstvom protivnika. Britanski RAF je, prema nemačkim podacima, u vremenu od 6. do 30. aprila, izgubio ukupno 151 vazduhoplov. ${ }^{65}$ Kada bude poznat ukupan broj letova i časova leta za sva vazduhoplovstva sila Osovine tokom napada na Kraljevinu Jugoslaviju, tada ćemo moći da po vazduhoplovnim kriterijumima utvrdimo učinak Vazduhoplovstva vojske i protivavionske odbrane. Dobijene rezultate uporedićemo sa onim što je u isto vreme uradila saveznička avijacija i tek tada imaćemo konačnu sliku o ulozi i mestu jugoslovenskog vazduhoplovstva u ovim istorijskim događajima. ${ }^{66}$

\section{Predrag Miladinović}

\section{THE LOSSES OF THE AXIS AVIATION IN THE APRIL WAR 1941}

\section{Summary}

The war in April 1941 was short and ended with the defeat of the Yugoslav Kingdom. This was the beginning of an chain of events whose consequences are felt to this day. A large number of Yugoslav casualties in the aerial attacks and superiority of the enemy, whose air forces had a significant role in the Yugoslav defeat, created the impression among the contemporaries about the impotence of the Yugoslav aviation and anti-aircraft defenses. Insight into the archives of the (former) enemies provides somehow different picture. More than 200 aircraft struck off charge (permanently or temporarily disabled), 164 of those during the 12 days of the April War just over and around Yugoslav soil, definitely is not the greatest loss of the Axis air forces in the Second World War. In Balkan campaign, on operation against Yugoslavia, Greece and Crete in April and May 1941, Axis air forces lost (permanently or temporarily disabled) approximately 700 aircraft. When compared with the German losses in campaign against Poland in September 1939 (some 400 airplanes) or during the attack on Low countries and France in May and June 1940 (some 1500 airplanes) the efficiency of the Yugoslav defenses can be judged with some approximate. Members of the aviation and anti-aircraft units, like the members of the army of the Yugoslav Kingdom as a whole, were neglected and forgotten after the war mainly by political reason, only to be remembered by their fatherland les than ten years ago, when some of them received long deserved decorations, in most cases posthumously.

${ }^{64}$ VA, P17, K37, F1, D14, L5, 8, 13, 16, 20, 21, 24, 29. - Za tri jugoslovenske letelice prijavljene 9. aprila od nemačkih pilota kao oborene, nema nikakve potvrde sa jugoslovenske strane. Jugoslovenski avioni oštećeni 12. aprila bili su onesposobljeni u napadima prethodnih dana.

${ }^{65}$ J. Prien et al, Die Jagdflieger..., 177.

${ }^{66}$ Još uvek nedostaju podaci o ukupnom naletu nemačke, britanske i grčke avijacije u aprilu 1941. 